\title{
Pyrenophora bromi, Causal Agent of Brownspot of Bromegrass, Expresses a Gene Encoding a Protein with Homology and Similar Activity to Ptr ToxB, a Host-Selective Toxin of Wheat
}

\author{
Rachael M. Andrie and Lynda M. Ciuffetti \\ Department of Botany and Plant Pathology, Oregon State University, Corvallis 97331, U.S.A.
}

Submitted 26 June 2010. Accepted 10 November 2010.

Ptr ToxB, encoded by ToxB, is one of multiple host-selective toxins (HST) produced by the wheat pathogen Pyrenophora tritici-repentis. Homologs of ToxB are found in several ascomycetes, including sister species Pyrenophora bromi, causal agent of brownspot of bromegrass. Due to the close evolutionary relatedness of $P$. tritici-repentis and $P$. bromi and that of their grass hosts, we hypothesized that homologs of ToxB in $P$. bromi may act as HST in the disease interaction between $P$. bromi and bromegrass. A representative set of transcriptionally active $P$. bromi ToxB genes were heterologously expressed in Pichia pastoris and the resultant proteins tested for their ability to act as HST on bromegrass. The tested Pyrenophora bromi ToxB (Pb ToxB) proteins were not toxic to bromegrass; thus, $\mathrm{Pb}$ ToxB does not appear to function as an HST in the $P$. bromi-bromegrass interaction. Instead, we revealed that the $\mathrm{Pb}$ ToxB proteins can be toxic to Ptr ToxB-sensitive wheat, at levels similar to Ptr ToxB, and the corresponding $P$. bromi ToxB genes are expressed in $P$. bromi-inoculated wheat. Our data suggest that $P$. bromi possesses the potential to become a wheat pathogen and highlights the importance of investigating the interaction between $P$. bromi and wheat.

Ptr ToxB (Orolaza et al. 1995; Strelkov et al. 1999) is one of multiple host-selective toxins (HST) produced by Pyrenophora tritici-repentis, causal agent of tan spot of wheat (Ciuffetti and Tuori 1999; De Wolf et al. 1998; Strelkov and Lamari 2003). It is a small, $6.5-\mathrm{kDa}$ protein encoded by the ToxB gene (Martinez et al. 2001) that induces chlorosis on the sensitive wheat differentials Katepwa and 6B662 (Lamari et al. 1995; Orolaza et al. 1995). Isolates of $P$. tritici-repentis are separated into races based on the complement of HST that they produce, with races 5 (Lamari et al. 1995), 6 (Strelkov et al. 2002), 7, and 8 (Lamari et al. 2003) containing up to an estimated 10 copies of Ptr ToxB-encoding genes, depending on the isolate (Lamari et al. 2003; Martinez et al. 2004; Strelkov et al. 2006). Furthermore, although they do not produce Ptr ToxB and are not pathogenic on Ptr ToxB-sensitive wheat, $P$. tritici-repentis races 3 and 4 each contain single-copy homologs of $T o x B$. In race 3 , all but the first six nucleotides of the ToxB-like sequence are identical

Corresponding author: L. M. Ciuffetti;

E-mail: ciuffetL@science.oregonstate.edu

Current address of R. M. Andrie: Division of Cardiovascular Medicine, Department of Medicine, Oregon Health and Science University, Portland 97239 . to ToxB (Strelkov and Lamari 2003, Strelkov et al. 2006); whereas, for race 4 , the sequences are more divergent (Martinez et al. 2004; Strelkov et al. 2006). The remaining non-Ptr ToxBproducing races of $P$. tritici-repentis lack ToxB homologs (Andrie et al. 2007; Martinez et al. 2004) but require other HST to be pathogenic (Andrie et al. 2007; Balance et al. 1996; Ciuffetti and Tuori 1999; De Wolf et al. 1998; Strelkov and Lamari 2003).

All of the ToxB homologs in P. tritici-repentis have been shown to be transcriptionally active. Initially, it was thought that transcription of the ToxB homologs in race 3, race 4, and a weakly virulent race 5 isolates was restricted to conidia (Strelkov et al. 2006), which is in contrast to both mycelial and conidial transcription of ToxB in a highly virulent race 5 isolate (Martinez et al. 2004; Strelkov et al. 2006). However, more sensitive detection methods have since shown that all $P$. triticirepentis ToxB homologs are expressed in both mycelia and conidia (Amaike et al. 2008). In addition, ToxB appears to confer virulence in a copy-number-dependent manner: i) a virulent race 5 isolate has a higher copy number and levels of ToxB expression than a weakly virulent race 5 isolate with fewer copies and lower transcript levels (Amaike et al. 2008) and ii) ToxB-containing transfomants with a higher copy number are more virulent when inoculated on Ptr ToxB-sensitive wheat than transformants with fewer copies (Ciuffetti et al. 2010).

Although evidence suggests that race 4 isolates of $P$. triticirepentis that contain a ToxB homolog (for convenience designated toxb and the corresponding protein designated Ptr toxb) possess a general pathogenic ability (Ciuffetti et al. 1997, 2010; Lamari and Bernier 1989; Larez et al. 1986), thus far they have not been shown to cause disease (Amaike et al. 2008; Cao et al. 2009). The absence of chlorosis-inducing activity by these isolates appears to be due to a combination of the extent of toxb/Ptr toxb expression and sequence differences in the gene or protein (Kim and Strelkov 2007). Not only is Ptr toxb undetectable in race 4 mycelium, spore germination fluids, and culture filtrates (Cao et al. 2009) but a combination of sequence and phylogenetic analyses suggests that toxb may be evolving toward a fate as a pseudogene (Andrie et al. 2008).

Recently, ToxB homologs also have been discovered in a broad range of plant-pathogenic ascomycetes (Andrie et al. 2008), including Pyrenophora bromi, the sister species of $P$. tritici-repentis (Zhang and Berbee 2001). P. bromi is the causal agent of brownspot of bromegrass (Bromus inermis) (Chamberlain and Allison 1945), the grass species most closely related to wheat (Barker et al. 2001; Hsiao et al. 1994). Due to the relatedness of $P$. bromi and $P$. tritici-repentis and 
their grass hosts, we hypothesized that the P. bromi ToxB homologs encode for HST involved in the interaction between $P$. bromi and bromegrass. In fact, due to the presence of chlorotic halos beyond the boundaries of fungal hyphae, a phytotoxin has been implicated in brownspot of bromegrass caused by $P$. bromi (Sherwood 1996). Furthermore, the P. bromi ToxB sequences appear to be conserved (Andrie et al. 2008).

To test the hypothesis that various $P$. bromi ToxB homologs encode for HST, we employed the approach developed by Martinez and associates (2001) for the characterization of the role of ToxB in the interaction between $P$. tritici-repentis and wheat. We heterologously expressed various transcriptionally active $P$. bromi ToxB sequences in a yeast expression system, followed by assessment of their toxicity on bromegrass. Although our results show that the products of the $P$. bromi ToxB genes do not function as HST in the interaction between $P$. bromi and bromegrass, we reveal that they are toxic to wheat, suggesting a potential for P. bromi to become a wheat pathogen.

\section{RESULTS}

The ToxB homologs in $P$. bromi are transcriptionally active.

To confirm that the ToxB homologs in P. bromi (for convenience tentatively named $\mathrm{Pb} T o x B$, and the corresponding proteins named $\mathrm{Pb}$ ToxB, to differentiate their species origin as $P$. bromi) (Andrie et al. 2008) are actively transcribed, we used semiquantitative reverse-transcriptase polymerase chain reaction (RT-PCR) to analyze RNA from $P$. bromi grown under conditions in which pathogenic $P$. tritici-repentis race 5 isolate DW7 is known to produce ToxB mRNA (Martinez et al. 2004). We first confirmed that our ToxB primers, TB7 and TB59, efficiently amplify both $P b$ ToxB and ToxB from $P$. bromi and $P$. tritici-repentis genomic DNA, respectively (data not shown). The results of semiquantitative RT-PCR analysis with these primers showed that various $P b$ ToxB genes from $P$. bromi are actively transcribed in culture (Fig. 1A). Furthermore, a comparison of the RT-PCR results for P. bromi isolates SM101 and SM106 (Fig. 1A) with the RT-PCR results for $P$. tritici-repentis isolate DW7 (Fig. 1B) suggests that the level of $P b$ ToxB expression is less than that for ToxB under the same conditions. Because we normalized the amount of fungal biomass in each PCR reaction by using the same amount of starting RNA for first-strand cDNA synthesis, adding the same amount of cDNA in subsequent PCR reactions, and loading the same amount of

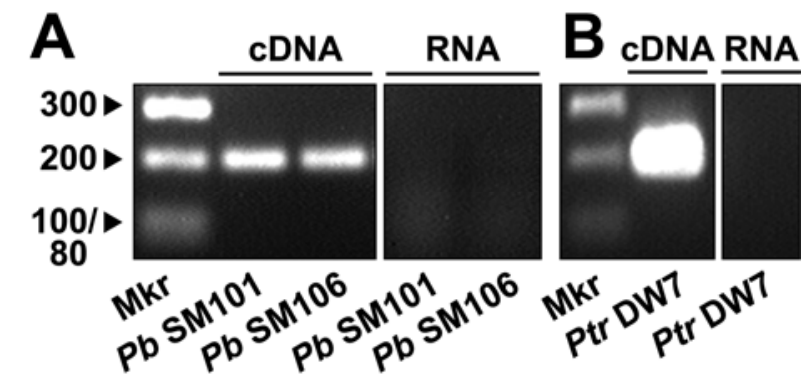

Fig. 1. Pyrenophora bromi ToxB ( $P b$ ToxB) homologs are actively transcribed in culture, although at lower levels than ToxB from a pathogenic $P$. tritici-repentis race 5 isolate. $\mathbf{A}$, Reverse-transcriptase polymerase chain reaction (RT-PCR) analysis of $P b$ ToxB expression from $P$. bromi isolates SM101 and SM106. B, RT-PCR analysis of ToxB expression from $P$. tritici-repentis race 5 isolate DW7. Amplification intensities were comparable between all isolates because equal amounts of starting RNA and cDNA were used for first-strand cDNA synthesis and subsequent PCR reactions, respectively. Equal amounts $(15 \mu \mathrm{l})$ of MassRuler DNA Ladder, Mix, ready-to-use (MBI Fermentas, Hanover, MD, U.S.A.) were loaded on each agarose gel. Band sizes are given in base pairs. $\mathrm{Mkr}=$ DNA mass ladder, $P b=P$. bromi, $P t r=P$. tritici-repentis.
DNA ladder on each gel, the intensity differences observed in Figure 1 should reflect quantitative differences between ToxB and $P b$ ToxB transcript levels. Similar results were obtained for P. bromi isolate Bf-1 (data not shown).

\section{Heterologous expression}

of representative $P b \operatorname{ToxB}$ homologs.

To determine whether various $P b$ ToxB homologs function as HST in the $P$. bromi-bromegrass interaction, we heterologously expressed representative $\mathrm{Pb}$ ToxB homologs following the approach developed by Martinez and associates (2001) used to confirm that ToxB encodes for the HST Ptr ToxB. $P$. tritici-repentis ToxB and toxb were similarly expressed to be used as positive and negative controls, respectively, of Ptr ToxB-induced symptom development. Representative $P b$ ToxB homologs were chosen for heterologous expression in Pichia pastoris based on the phylogenetic relationships of the deduced $\mathrm{Pb}$ ToxB amino acid sequences (Fig. 2A). At least one

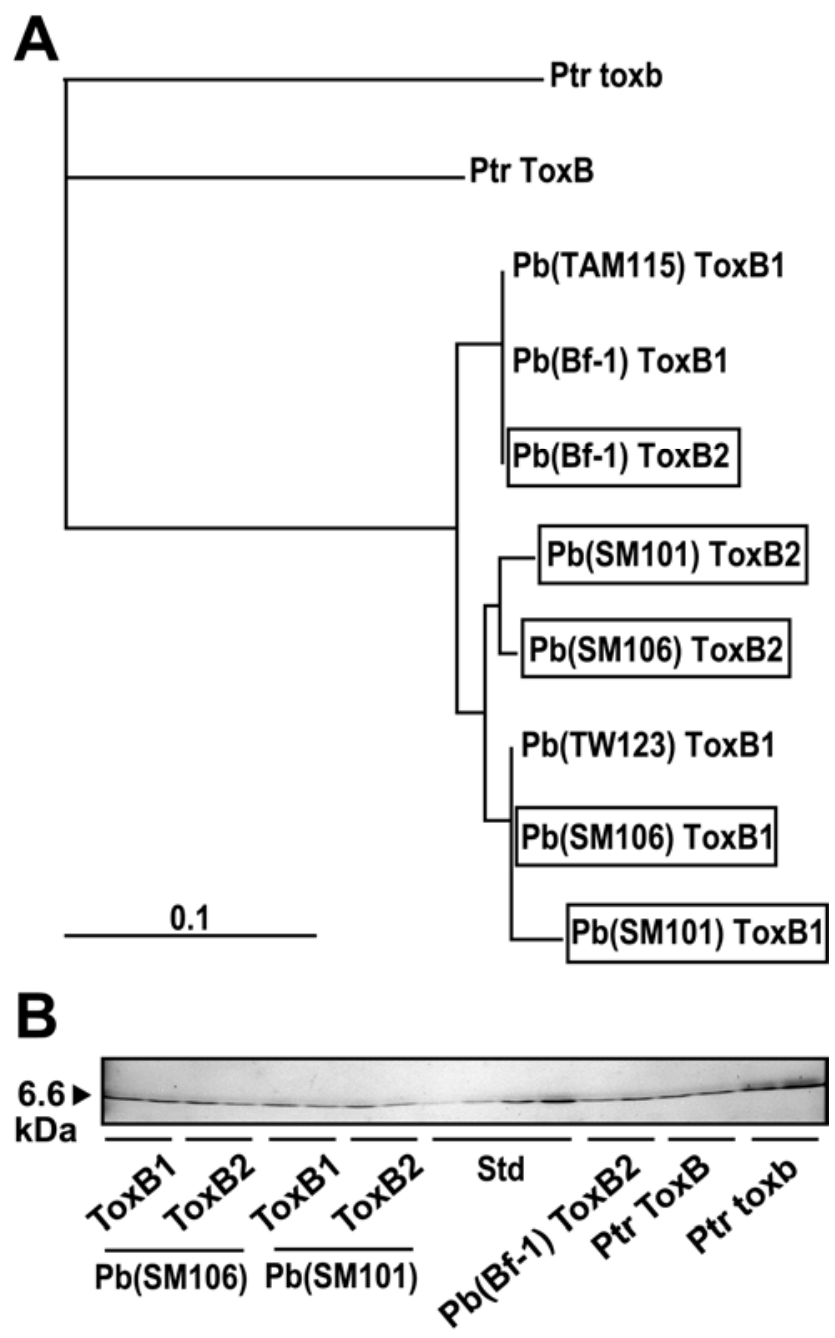

Fig. 2. Heterologous expression of ToxB homologs from Pyrenophora bromi. A, A subset of $\mathrm{Pb}$ ToxB genes was chosen for heterologous expression based on their phylogenetic relationships as revealed by a distance analysis of the deduced $\mathrm{Pb}$ ToxB amino acid sequences (Andrie et al. 2008). Chosen loci are demarcated with a box. B, Culture filtrates containing heterologously expressed $\mathrm{Pb}$ ToxB, Ptr toxb, and Ptr ToxB proteins were analyzed by $13 \%$ sodium dodecyl sulfate polyacrylamide gel electrophoresis. Each culture filtrate was loaded in duplicate and paired lanes are grouped by black lines above protein names. The gel was silver-stained for densitometric quantitation of the expressed proteins (average of duplicate band intensities) via comparison with a set of known amounts of homogeneous native Ptr ToxB standards (Std), including 75, 150, 225, and $350 \mathrm{ng}$ (from left to right). 
representative from each of the three observed $\mathrm{Pb}$ ToxB clades was chosen for heterologous expression. Furthermore, two additional $\mathrm{Pb}$ ToxB genes were also chosen for expression, such that all of the protein products found in the $P$. bromi isolates SM101, SM106, and Bf-1 were represented. In total, five $\mathrm{Pb}$ ToxB loci were chosen for heterologous expression, including $P b$ (SM106) ToxB1 and $P b$ (SM106) ToxB2 from P. bromi isolate $\mathrm{SM} 106, \mathrm{~Pb}(\mathrm{SM} 101) \mathrm{ToxB1}$ and $\mathrm{Pb}(\mathrm{SM} 101)$ ToxB2 from $P$. bromi isolate SM101, and $P b(\mathrm{Bf}-1)$ ToxB1 from $P$. bromi isolate $\mathrm{Bf}-1$. Furthermore, as shown in the tree in Figure 2A, $P b(\mathrm{Bf}-1) T o x B 2$ and $P b$ (TAM115) ToxB1 are identical to $P b(\mathrm{Bf}-1)$ ToxBl, and $P b(\mathrm{TW} 123)$ ToxB1 is identical to $P b$ (SM106) ToxB1; thus, results obtained from analysis of heterologously expressed $P b(\mathrm{Bf}-1)$ ToxB1 and $P b(\mathrm{SM} 106)$ ToxB1 should be applicable to these other proteins.

The protein products encoded by selected ToxB homologs are shown on the gel in Figure 2B. Because there is a small minority of high molecular weight Pichia pastoris proteins present in the culture filtrates of heterologously expressed ToxB homologs, traditional quantitation methods to normalize protein concentrations could not be employed (data not shown). Therefore, sodium dodecyl sulfate polyacrylamide gel electrophoresis (SDS-PAGE) was used for densitometric quantitation of each ToxB protein sample (loaded in duplicate) compared with a standard curve of known amounts of homogeneous native Ptr ToxB. Heterologously expressed $\mathrm{Pb}$ ToxB proteins were of similar size to Ptr ToxB, which is $6.5 \mathrm{kDa}$. Samples containing heterologously expressed Ptr toxb protein contain three bands, one similar in size to Ptr ToxB and a slightly larger doublet (Fig. 3A). All three Ptr toxb bands are recognized by Ptr ToxB antisera (Fig. 3B), although at a lower affinity than for Ptr ToxB (Figs. 3B [prolonged exposure time] and 4). For the purposes of densitometric quantitation, these bands were purposely not separated so that all forms of $\mathrm{Ptr}$ toxb would be represented in a single band (Fig. 2B).

\section{Heterologously expressed $\mathrm{Pb}$ ToxB proteins are recognized by anti-Ptr ToxB antisera.}

Western analysis was performed to determine the affinity of anti-Ptr ToxB antisera for the various $\mathrm{Pb}$ ToxB proteins (Fig. 4). Initially, we loaded equal amounts of all of the heterologously expressed proteins; however, the Ptr ToxB recognition signal overwhelmed the signal of any of the other proteins (data not shown). Therefore, we subsequently loaded 10-fold more of each $\mathrm{Pb}$ ToxB (750 ng) and of Ptr toxb (750 ng) compared with Ptr ToxB (75 ng). The anti-Ptr ToxB antisera recognized $\mathrm{Pb}$ ToxB and $\mathrm{Ptr}$ toxb, although with at least 10 -fold less affinity than for Ptr ToxB, as shown by a similar signal for the

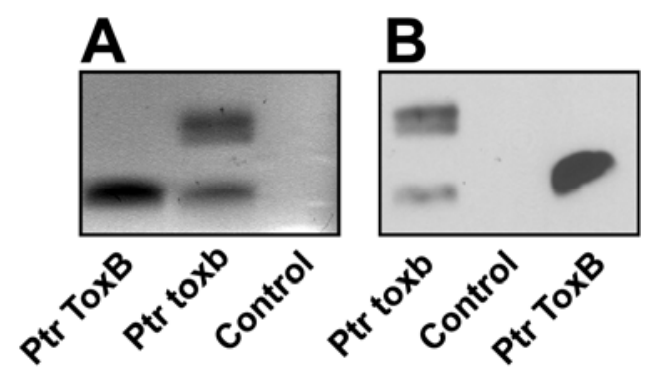

Fig. 3. Culture filtrates produced by heterologous expression of toxb contain three protein bands recognized by anti-Ptr ToxB antisera. A, Culture filtrates containing Ptr ToxB (150 ng), Ptr toxb (150 ng), and vector alone (control) were resolved by $13 \%$ sodium dodecyl sulfate polyacrylamide gel electrophoresis. Proteins were detected by silver stain. B, Western blot analysis of heterologously expressed Ptr ToxB (75 ng), Ptr toxb (750 ng), and vector alone (control) with anti-Ptr ToxB antisera. Detection of all three Ptr toxb bands required a prolonged exposure time.

$\mathrm{Pb}$ ToxB proteins and less intense signal for Ptr toxb despite loading 10-fold more $\mathrm{Pb}$ ToxB and Ptr toxb on the gel (Fig. 4). Ptr toxb signal under these conditions is very weak; a prolonged exposure is required to observe the second set of bands (data not shown), observed in Figure 3B. Finally, culture filtrate of our vector-alone control was not cross-reactive with the Ptr ToxB antisera (Figs. 3B and 4, control), ruling out nonspecific interactions of anti-Ptr ToxB antisera with Pichia proteins.

$\mathrm{Pb}$ ToxB had no effect on tested bromegrass, despite the high susceptibility of bromegrass to Pyrenophora bromi.

If $\mathrm{Pb}$ ToxB functions as an HST in the interaction between $P$. bromi and bromegrass, infiltration of $\mathrm{Pb}$ ToxB proteins alone would be expected to reproduce disease symptoms on correspondingly susceptible host plants. Concentrations for infiltration of $9.5 \mathrm{ng} / \mu \mathrm{l}(1.4 \mu \mathrm{M}), 19 \mathrm{ng} / \mu \mathrm{l}(2.88 \mu \mathrm{M})$, and 38 $\mathrm{ng} / \mu \mathrm{l}(5.76 \mu \mathrm{M})$ were chosen based on the physiologically relevant concentrations previously published in the $P$. triticirepentis-wheat interaction literature for Ptr ToxB purified from crude culture filtrates (Strelkov et al. 1999) and for heterologously expressed Ptr ToxB (Martinez et al. 2001). Infiltration of heterologously expressed $\mathrm{Pb}$ ToxB proteins into three bromegrass cultivars (Baylor, PL-BDR1, and a commercial cultivar) at the highest concentration chosen for infiltration (38 $\mathrm{ng} / \mu \mathrm{l})$ failed to elicit symptoms on bromegrass (Fig. 5A, representative bromegrass leaf infiltrated with $\mathrm{Pb}$ ToxB), despite the fact that these are all highly susceptible to $P$. bromi upon inoculation (Fig. 5B, representative bromegrass leaf inoculated with P. bromi).

Because the P. bromi isolates SM101 and SM106 each contain two different $\mathrm{Pb}$ ToxB loci, it is possible that the formation of a $\mathrm{Pb}$ ToxB heterodimer is necessary for toxicity on bromegrass. To investigate this possibility, both variants from SM101 (Pb[SM101] ToxB1 and $\mathrm{Pb}[\mathrm{SM} 101] \mathrm{ToxB} 2)$ or SM106 ( $\mathrm{Pb}$ [SM106] ToxB1 and $\mathrm{Pb}[\mathrm{SM} 106]$ ToxB2) were mixed and co-infiltrated into bromegrass; however, there still was no effect (data not shown). Ptr ToxB, Ptr toxb, and the vector-only control also did not cause any reactions on bromegrass (Fig. 5A). Our results indicate that $\mathrm{Pb}$ ToxB does not function as an HST in brownspot of bromegrass caused by $P$. bromi, at least among the isolate-cultivar combinations we tested.

\section{The $\mathrm{Pb}$ ToxB proteins are toxic}

to $P \operatorname{tr}$ ToxB-sensitive wheat but not insensitive wheat.

To investigate whether $\mathrm{Pb}$ ToxB is toxic to wheat, culture filtrates of heterologously expressed $\mathrm{Pb}$ ToxB proteins were

\section{$750 \mathrm{ng}$}

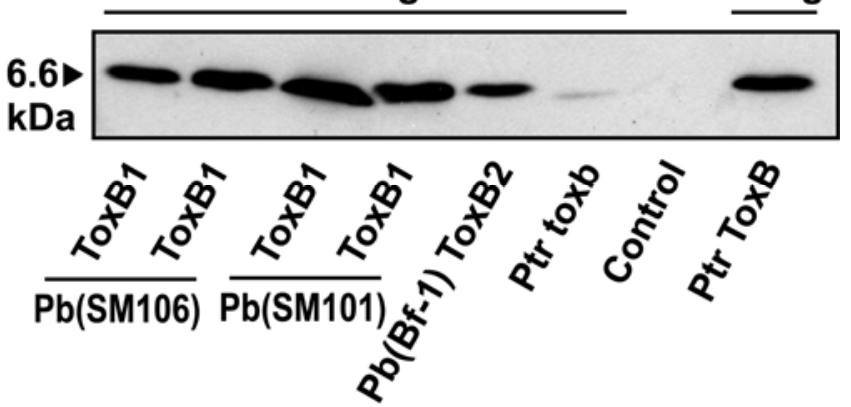

Fig. 4. Heterologously expressed $\mathrm{Pb}$ ToxB and $\mathrm{Ptr}$ toxb are recognized by Ptr ToxB antisera, although with lower affinity than for Ptr ToxB. Culture filtrates containing $750 \mathrm{ng}$ of each $\mathrm{Pb}$ ToxB protein and of Ptr toxb, as well as $75 \mathrm{ng}$ of Ptr ToxB, were separated by $13 \%$ sodium dodecyl sulfate polyacrylamide gel electrophoresis followed by Western blot analysis with anti-Ptr ToxB antisera. Control = culture filtrate from a Pichia pastoris clone transformed with the $\mathrm{pPICZ} \alpha \mathrm{B}$ vector alone. 
infiltrated into Ptr ToxB-sensitive wheat compared with Ptr ToxB, Ptr toxb, and a vector-only control (Fig. 5C, wheat line 6B662). As expected, infiltration of Ptr ToxB resulted in characteristic chlorosis, the intensity of which increased with increasing concentrations of toxin applied. Additionally, no symptoms at any of the three concentrations applied were elicited from infiltration of Ptr toxb or the control. However, a range of symptoms was elicited on Ptr ToxB-sensitive wheat upon infiltration of the various $\mathrm{Pb}$ ToxB proteins. $\mathrm{Pb}(\mathrm{Bf}-1)$ ToxB1 from $P$. bromi isolate $\mathrm{Bf}-1$ gave no reaction at any concentration. $\mathrm{Pb}$ (SM106) ToxB1 from SM106 only caused chlorosis at the highest concentration, $38 \mathrm{ng} / \mu \mathrm{l}$. $\mathrm{Pb}(\mathrm{SM} 106)$ ToxB2 from $\mathrm{SM} 106$ and $\mathrm{Pb}(\mathrm{SM} 101)$ ToxB2 from SM101 gave hints of chlorosis at $9.5 \mathrm{ng} / \mu \mathrm{l}$, which intensified at the higher concentrations of 19 and $38 \mathrm{ng} / \mu \mathrm{l}$ but never reached the levels of chlorosis caused by Ptr ToxB. Finally, Pb(SM101) ToxB1 from isolate SM101 produced symptoms similar to Ptr ToxB at all three concentrations. Based on the phylogenetic relationships between the $\mathrm{Pb}$ ToxB proteins (Fig. $2 \mathrm{~A}$ ), $\mathrm{Pb}(\mathrm{Bf}-1)$ ToxB2, the other $\mathrm{Pb}$ ToxB from $\mathrm{Bf}-1$, and $\mathrm{Pb}$ (TAM115) ToxB1, the only locus identified in P. bromi isolate TAM115, are expected to be inactive like $\mathrm{Pb}(\mathrm{Bf}-1)$ ToxB1. Additionally, $\mathrm{Pb}(\mathrm{TW} 123)$
ToxB1, the only locus identified in $P$. bromi isolate TW123, is expected to cause chlorosis only at the highest concentration tested, similar to $\mathrm{Pb}(\mathrm{SM} 106)$ ToxB1. Similar results were also obtained for infiltration of culture filtrates of all of the heterologous proteins into the Ptr ToxB-sensitive wheat cv. Katepwa (data not shown). Additionally, none of the $\mathrm{Pb}$ ToxB proteins elicited chlorosis on the insensitive cv. Auburn (data not shown). Thus, the observed activity of $\mathrm{Pb}$ ToxB on wheat appears to be cultivar-specific like Ptr ToxB.

\section{$P$. bromi shares a similar phenotype with nonpathogenic $P$. tritici-repentis race 4 isolates in its interaction with Ptr ToxB-sensitive wheat.}

Due to the observation that some of the $\mathrm{Pb}$ ToxB proteins are toxic to wheat, we next determined whether isolates of $P$. bromi cause disease on wheat. Although various $\mathrm{Pb}$ ToxB proteins are capable of eliciting chlorosis upon infiltration (Fig. 5C), inoculation of Ptr ToxB-sensitive wheat with P. bromi isolates carrying the corresponding $P b$ Tox $B$ genes does not result in symptom development (Fig. 5B, representative wheat leaves inoculated with $P$. bromi and a $P$. tritici-repentis race 5 isolate). Instead, all P. bromi isolates tested (Fig. 5B, isolate SM101;

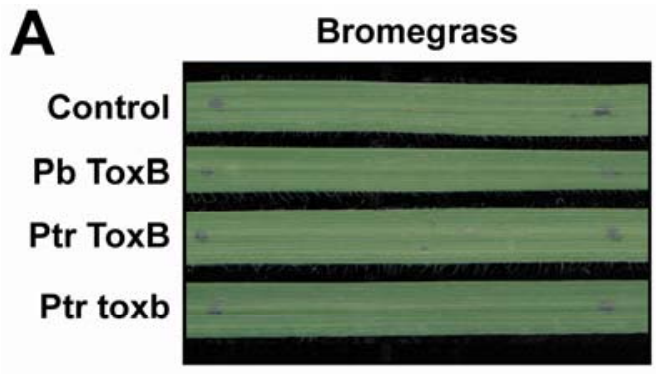

B

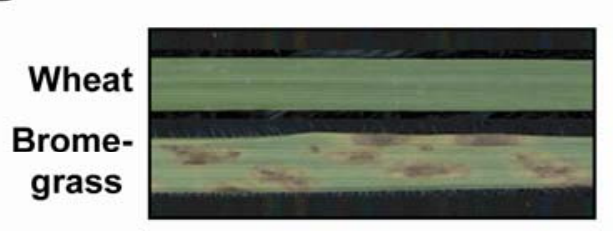

Ptr

Race 5

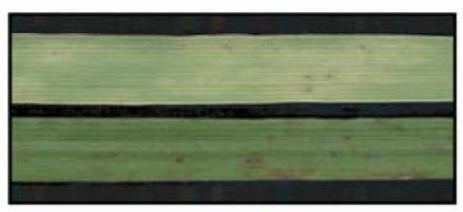

Ptr

Race 4

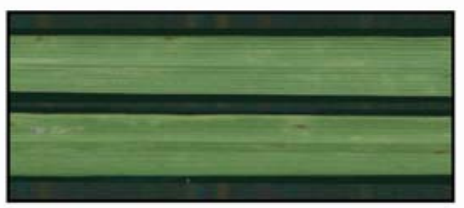

C

Wheat

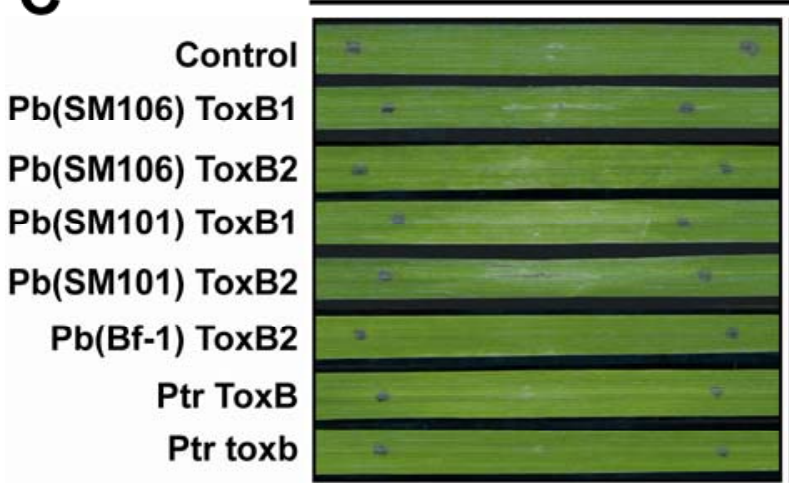

$9.5 \mathrm{ng} / \mu \mathrm{l}$

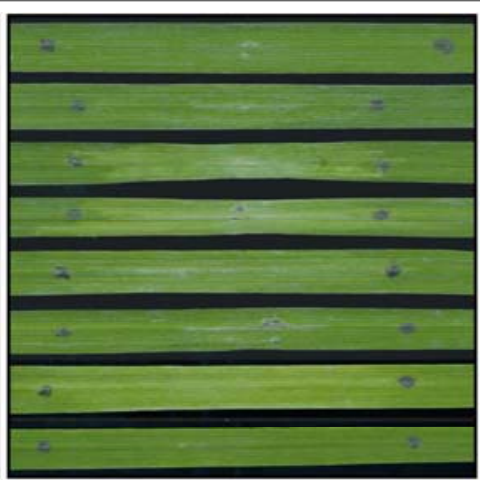

$19 \mathrm{ng} / \mu \mathrm{l}$

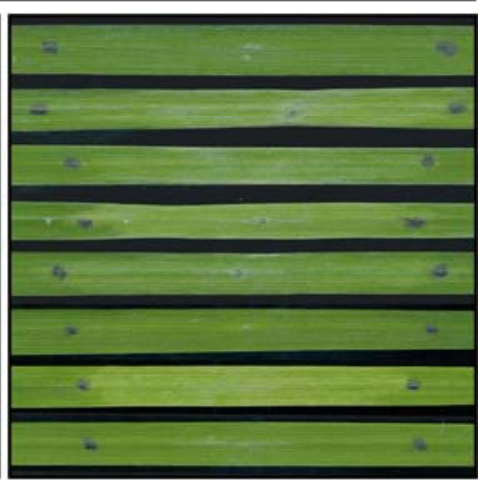

$38 \mathrm{ng} / \mu \mathrm{l}$

Fig. 5. $\mathrm{Pb}$ ToxB proteins can elicit chlorosis on Ptr ToxB-sensitive wheat, although lack any phytotoxic activity on smooth bromegrass susceptible to Pyrenophora bromi. A, Infiltration of culture filtrates containing heterologously expressed $\mathrm{Pb}$ ToxB, Ptr ToxB, and Ptr toxb into bromegrass. Infiltrations were done at a concentration of $38 \mathrm{ng} / \mu \mathrm{l}$. One representative leaf of each infiltration is shown. B, Inoculation of Ptr ToxB-sensitive wheat (here, the wheat line 6B662) and bromegrass with $P$. bromi (which possesses two copies of $P b$ ToxB), $P$. tritici-repentis race 5 (which possesses 8 to 10 copies of ToxB), and $P$. tritici-repentis race 4 (which possesses 1 copy of toxb). C, Infiltration of heterologously expressed $\mathrm{Pb}$ ToxB, Ptr ToxB, and Ptr toxb into the Ptr ToxB-sensitive wheat cultivar 6B662. Infiltrations were done at a range of concentrations, including: $9.5,19$, and $38 \mathrm{ng} / \mu \mathrm{l}$. Control = culture filtrate from a Pichia pastoris clone transformed with the pPICZ $\alpha \mathrm{B}$ vector alone. Similar results were obtained with the Ptr ToxB-sensitive cv. Katepwa (data not shown). 
isolates SM106 and Bf-1, data not shown) elicited a response similar to that caused by the nonpathogenic race 4 isolate of $P$. tritici-repentis on Ptr ToxB-sensitive wheat (Fig. 5B). Neither race 4 nor race 5 isolates of $P$. tritici-repentis exhibited a pathogenic reaction when inoculated on bromegrass (Fig. 5B). As expected, $P$. bromi and $P$. tritici-repentis race 5 exhibited typical disease development on their respective hosts (Fig. 5B).

\section{$\mathrm{Pb}$ ToxB is expressed}

\section{in Ptr ToxB-sensitive wheat inoculated with $P$. bromi.}

One explanation for why our P. bromi isolates did not cause disease on Ptr ToxB-sensitive wheat, despite possessing genes that encode for phytotoxic proteins, is that the genes are not expressed, or are not expressed to sufficient levels, in the host. Thus, we used semiquantitative RT-PCR to determine whether $P b$ ToxB, specifically for $P$. bromi isolates SM101 and SM106, is expressed in $P$. bromi-inoculated wheat (Fig. 6A). Furthermore, $\mathrm{Pb}$ ToxB transcript amounts were compared with the amount of transcript detectable in wheat inoculated with a $P$. tritici-repentis race 5 isolate that causes significant levels of chlorosis (Fig. 6B). We chose glyceraldehyde-3-phosphate dehydrogenase $(g p d)$ as a control for fungal biomass within a mix of plant and fungal RNA because of its successful use as a reliable reference gene in previous expression analyses of other fungus-host interactions (Fang and Bidochka 2006; Grell et al. 2005). Additionally, we confirmed that the primers gpdl and gpd2 amplified gpd from $P$. bromi and P. triticirepentis genomic DNA at similar levels (data not shown).

For our comparison of in planta $P b$ ToxB expression by $P$. bromi in sensitive wheat to that of ToxB by $P$. tritici-repentis, we chose to extract RNA from plants at 2 days postinoculation (dpi) for the following reasons. First, Amaike and associates (2008) recently showed that ToxB transcript abundance peaks at 1 to $2 \mathrm{dpi}$ in planta, prior to the onset of plant resistance mechanisms. Thus, detection of $P b$ Tox $B$ mRNA at 2 dpi would place $\mathrm{Pb}$ ToxB protein production at the right time and right place to cause disease. Second, because it was previously shown that infection by $P$. tritici-repentis proceeds similarly up to $48 \mathrm{~h}$ in both susceptible and resistant plants, after which either disease progresses or plant defense responses halt pathogen ingress, respectively (Dushnicky et al. 1998), and that the infection phenotypes on wheat for both $P$. tritici-repentis race 5 and $P$. bromi look similar up to this point before diverging significantly (data not shown), we expect that the fungal bur- den of $P$. tritici-repentis and $P$. bromi is likely similar up to this point and, therefore, dilution of the fungal signal in a majority of plant transcripts will be comparable between the two. Third, by 2 dpi (on both resistant and susceptible cultivars), 95\% of surface conidia have germinated and dehydrated, and their associated RNA degraded (De Wolf et al. 1998; Larez et al. 1986), thereby assuring that all fungal RNA detected originates from viable fungal mass within the plant.

Our results reveal that $P b$ ToxB mRNA is expressed at 2 dpi in wheat inoculated with $P$. bromi (Fig. 6A). The presence of stable $P$. bromi mRNA confirms that $P$. bromi is indeed viable during the first 2 days of its interaction with wheat. Furthermore, noninoculated controls confirm that our gpd primers do not recognize plant gpd sequences (Fig. 6C); therefore, all gpd amplification products are fungal specific. Amplification levels of the gpd transcript show that similar amounts of fungal biomass are present for both $P$. bromi (Fig. 6A) and P. triticirepentis (Fig. 6B) at $2 \mathrm{dpi}$; thus, any differences observed between $\mathrm{Pb}$ ToxB and ToxB transcript amounts should represent quantitative differences between the expression levels of these genes. In other words, $P b$ ToxB is expressed by $P$. bromi in wheat at levels considerably lower (Fig. 6A) than ToxB in wheat inoculated with $P$. tritici-repentis (Fig. 6B).

\section{DISCUSSION}

We previously reported that homologs of ToxB from $P$. tritici-repentis are found in several ascomycetes, including sister species $P$. bromi. Due to the close evolutionary relatedness of $P$. tritici-repentis and P. bromi, and that of their grass hosts, we investigated whether the homologs of ToxB in P. bromi act as HST in the disease interaction between P. bromi and bromegrass. Our results reveal that heterologously expressed $\mathrm{Pb}$ ToxB proteins are phytotoxic to Ptr ToxB-sensitive wheat (Fig. 5C) instead of to bromegrass (Fig. 5A), as we had predicted. Furthermore, we show that the corresponding $\mathrm{Pb}$ ToxB genes are actively transcribed, both in culture (Fig. 1A) and in $P$. bromi-inoculated wheat (Fig. 6A), Thus, although P. bromi possesses the pathogenic potential to cause disease on wheat, it does not. Instead, the interaction phenotype of $P$. bromi with Ptr ToxB-sensitive wheat is more similar to that of nonpathogenic $P$. tritici-repentis race 4 isolates (Fig. 5B).

The fact that ToxB appears to confer virulence in a copynumber-dependent manner (Amaike et al. 2008, Ciuffetti et

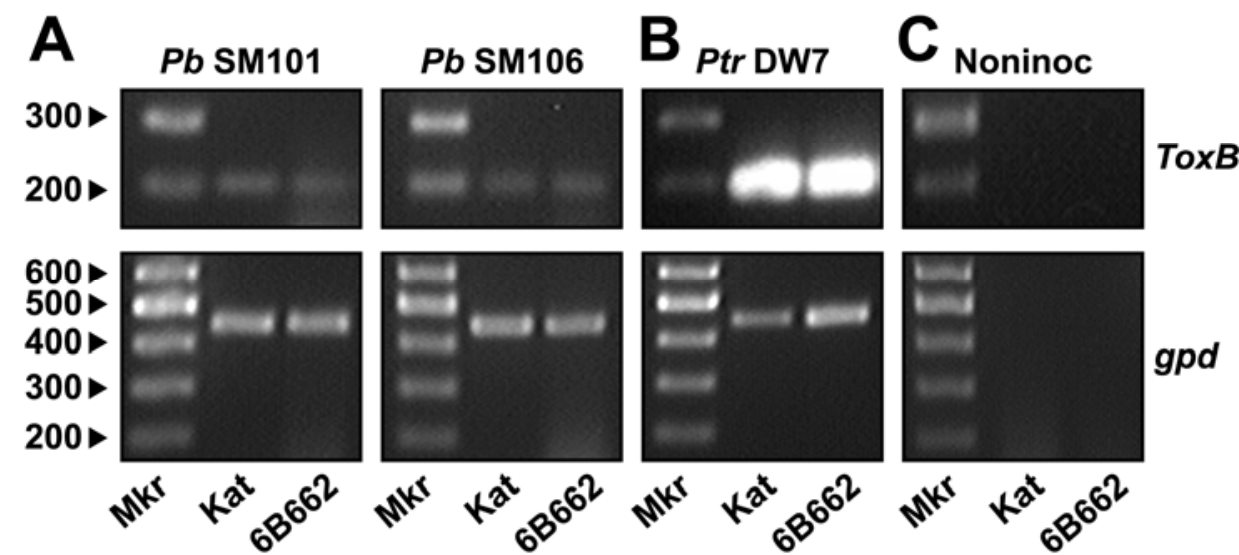

Fig. 6. $P b$ ToxB is transcribed in Ptr ToxB-sensitive wheat that has been inoculated with Pyrenophora bromi, although at levels less than $P$. tritici-repentis $T o x B$. A, In planta semiquantitative reverse transcriptase-polymerase chain reaction (RT-PCR) analysis of $P b$ Tox $B$ and glyceraldehyde-3-phosphate dehydrogenase $(g p d)$ expression in the Ptr ToxB-sensitive wheat line 6B662 and cv. Katepwa inoculated with the P. bromi isolates SM101 and SM106. B, In planta semiquantitative RT-PCR analysis of ToxB and gpd expression in 6B662 and Katepwa inoculated with the $P$. tritici-repentis race 5 isolate DW7. C, In planta RT-PCR analysis of noninoculated wheat controls. Equal amounts (15 $\mu \mathrm{l})$ of MassRuler DNA Ladder, Mix, ready-to-use (MBI Fermentas, Hanover, MD, U.S.A.) were loaded on each agarose gel. Mkr $=$ MassRuler DNA Ladder, $P b=P$. bromi, Ptr $=$ P. tritici-repentis, Kat $=$ Katepwa. 
al. 2010) provides insight into a possible explanation for why $P$. bromi is unable to cause disease on wheat, despite possessing genes encoding proteins that are toxic to wheat. Similar to the low-virulent race 5 isolate of $P$. tritici-repentis, which has only two copies of ToxB and a concomitant lower level of gene expression and disease elicitation compared with highly virulent $P$. tritici-repentis race 5 isolates that possess eight to 10 copies of $T o x B$ (Amaike et al. 2008), the $P$. bromi isolates used in this study have two copies of $P b$ ToxB (Andrie et al. 2008). Therefore, the inability of these $P$. bromi isolates to cause disease on wheat may be due to levels of $P b$ ToxB expression below those necessary to produce enough active $\mathrm{Pb}$ ToxB protein to overcome the onset of plant resistance responses by wheat. Indeed, the results of our semiquantitative RT-PCR studies, which show that phytoactive $P b$ ToxB genes are expressed at much lower levels than ToxB both in culture (Fig. 1) and in Ptr ToxB-sensitive wheat (Fig. 6), are consistent with this explanation. Further support can be found in the dose dependence of symptoms in our infiltration bioassay (Fig. 5C). Because P. bromi is viable in wheat (Fig. 6A), it is plausible that, with the acquisition of higher levels of $\mathrm{Pb}$ ToxB expression, whether via an increase in promoter strength or an increase in copy number of these genes, it could become a pathogen of wheat.

Indeed, fungal genomes are known for their variability, plasticity and flexibility (Zolan 1995). The widespread presence of transposable elements and other repetitive DNA sequences in fungal genomes provides the raw material necessary for gene duplication and gene shuffling (Thon et al. 2006; Turgeon and Baker 2007). Specifically, the genome of $P$. tritici-repentis has been shown to be highly plastic (Aboukhaddour et al. 2009; Lichter et al. 2002) and the truncated transposon-like sequences associated with ToxB have been implicated in the multiplication of this gene (Martinez et al. 2004; Strelkov et al. 2006). Similarly, the $P b$ ToxB loci are associated with unique upstream repetitive insertion-deletion (indel) sequences $25 \mathrm{bp}$ in length (tandemly arrayed as either 25, 50, 75, or $150 \mathrm{bp}$ ) (Andrie et al. 2008), which conceivably could provide a means for unequal crossing over and the potential for gene amplification or rearrangement. Furthermore, recent phylogenomic analyses of fungi in the Ascomycota have implicated gene inventory flux (expansion and contraction) as an important virulence-associated process (Powell et al. 2008) and shown that regulatory changes in gene expression are clearly coupled to adaptive changes in fungal lifestyle (Thompson and Rekev 2009; Wohlbach et al. 2009). Therefore, it is conceivable that the $P$. bromi genome could change in such a way to increase $P b$ ToxB expression to levels that we believe would be required for $P$. bromi to cause disease on wheat.

We had initially predicted that the variable chlorotic activities (Fig. 5C) arising from the different $\mathrm{Pb}$ ToxB protein sequences (Andrie et al. 2008) would provide us an obvious window into the active amino acid residues of Ptr ToxB; however, a detailed analysis of these data revealed the situation to be more enigmatic than predicted. First, 12 of the 15 amino acid differences between Ptr ToxB and the Pb ToxB sequences are shared by all of the $\mathrm{Pb}$ ToxB proteins regardless of their chlorosis-inducing activity on wheat or the lack thereof. Therefore, these residues provide no obvious insight into the residues important for Ptr ToxB activity. Second, a straightforward interpretation of two of the remaining three amino acid differences between $\mathrm{Ptr}$ ToxB and the $\mathrm{Pb}$ ToxB sequences is confounded when Ptr toxb, which is inactive, is also included in the analysis. Specifically, at position $34, \operatorname{Ptr}$ ToxB has a glutamic acid (E), functional $\mathrm{Pb}$ ToxB proteins have a glutamine $(\mathrm{Q})$, and nonfunctional $\mathrm{Pb}$ ToxB proteins have an arginine $(\mathrm{R})$ (Andrie et al. 2008). Although a change from $E$ to $Q$ is predicted as a likely substitution and $\mathrm{E}$ to $\mathrm{R}$ is not (Henikoff and Henikoff 1992), which correlates well with activity versus inactivity of the various $\mathrm{Pb}$ ToxB proteins, inactive Ptr toxb also shares an identical residue (E) in this position with Ptr ToxB. Furthermore, in another apparent contradiction, the most highly active $\mathrm{Pb}$ ToxB, $\mathrm{Pb}(\mathrm{SM} 101)$ ToxB1, and the inactive Ptr toxb both share a leucine (L) with Ptr ToxB at position 59 (Andrie et al. 2008). These observations have led us to conclude that the activity of Ptr ToxB is more complicated than just being attributable to single amino acid residues; rather, it possibly involves the formation of proper three-dimensional conformation or distant residues being brought together in the final protein conformation, analogous to signal patches involved in protein sorting (Pfeffer and Rothman 1987). Despite the aforementioned sequence enigmas, the greater affinity of the anti-Ptr ToxB antibody for the various $\mathrm{Pb}$ ToxB proteins compared with its reduced affinity for Ptr toxb (Fig. 4) provides support that the $\mathrm{Pb}$ ToxB proteins and Ptr ToxB are more similar to each other than either is to Ptr toxb. To delineate which areas of the Ptr ToxB protein sequence are important to function, we are taking a domain-swapping approach between Ptr ToxB, Ptr toxb, and various $\mathrm{Pb}$ ToxB proteins.

The fact that $\mathrm{Pb}$ ToxB does not function as an HST in the interaction between $P$. bromi and bromegrass does not preclude that a phytotoxin is involved in brownspot of bromegrass disease. First, many members of the Pleosporales, the order to which P. bromi belongs (Eriksson 2005; Schoch et al. 2006), are known to produce HST (Friesen et al. 2008; Walton 1996; Wolpert et al. 2002) or have been shown to produce toxic culture filtrates that correlate with disease symptoms (Strange 2007). Second, in addition to the HST produced by $P$. triticirepentis, a diversity of phytotoxic metabolites has been specifically described for other grass pathogens in the genus Pyrenophora. Three toxins whose activity correlate with disease have been isolated from culture filtrates of Pyrenophora teres, causal agent of net blotch of barley, two of which are secondary metabolites (Weiergang et al. 2002) and one of which is proteinaceous (Sarpeleh et al. 2007). Pyrenophora graminea, causal agent of leaf stripe disease of barley, produces a high molecular weight glycoprotein in culture filtrates, the carbohydrate portion of which is involved in its interaction with barley (Haegi and Porta-Puglia 1995). Finally, Pyrenophora semeniperda culture filtrates contain metabolites that are selectively toxic to susceptible hosts, although the nature of the active compounds remains to be characterized (Campbell et al. 2003). To identify an alternate phytotoxic activity involved in the interaction between $P$. bromi and bromegrass, culture filtrates of $P$. bromi will have to be analyzed similarly to the analysis done for the identification of other phytotoxins. Alternatively, the advent of low-cost, high-throughput, DNAsequencing technologies might make large-scale functional genomics the approach of choice (Soanes et al. 2007; Xu et al. 2006) to unravel the interaction of $P$. bromi with both wheat and bromegrass.

Our results suggest that there is a potential for P. bromi to become a pathogen of wheat. Although there is no current indication in the literature that P. bromi associates with wheat, it has been identified in association with other grasses (Sampson and Watson 1985). Furthermore, because P. bromi and nonpathogenic $P$. tritici-repentis look nearly identical and suffer misidentifications (Ali and Francl 2003; De Wolf et al. 1998), there is likely a higher incidence of $P$. bromi on wheat than we currently suspect. Together, this points to a need to revitalize our efforts to survey for $P$. bromi on wheat, other cereals, and non-cereal grasses and continue our investigations to elucidate the function of ToxB and its homologs, all in an effort to halt the development of an emergent disease. 


\section{MATERIALS AND METHODS}

Fungal isolates and plant material.

The isolates used in this study included the $P$. tritici-repentis race 4 isolate SD20 (Martinez et al. 2004); the $P$. tritici-repentis race 5 isolate DW7 (Ali et al. 1999); and the P. bromi isolates SM101, SM106, and Bf-1 (Andrie et al. 2008). Culture conditions are published elsewhere (Andrie et al. 2007). The smooth bromegrass cultivars used in this study included the line PLBDR1 (Berg et al. 1989) and cv. Baylor, both obtained from the U.S. National Plant Germplasm System, United States Department of Agriculture-Agricultural Research Service, Western Regional PI Station (Pullman, WA, U.S.A.), as well as a commercial cultivar obtained from Outsidepride.com, Inc. (Independence, OR, U.S.A.). For wheat, the Ptr ToxB-sensitive cv. Katepwa and line 6B662 (Lamari et al. 1995) and the resistant cv. Auburn (Andrie et al. 2007; Ciuffetti and Tuori 1999; Tomas and Bockus 1987; Tomas et al. 1990; Tuori et al. 1995) were used. Prior to inoculation or infiltration, smooth bromegrass was grown in a peat-vermiculite $(1: 1) \operatorname{mix}$ for 4 to 5 weeks and wheat was grown in soil for 2 to 3 weeks under diurnal conditions of light for $16 \mathrm{~h}$ at $23^{\circ} \mathrm{C}$ and darkness for $8 \mathrm{~h}$ at $19^{\circ} \mathrm{C}$.

\section{Fungal inoculation of plant hosts.}

Conidial concentrations for inoculation of smooth bromegrass and wheat were $1.25 \times 10^{3}$ conidia/ml (Zeiders and Sherwood 1986) and $3 \times 10^{3}$ conidia/ml (Lamari and Bernier 1989), respectively, regardless of whether P. bromi or P. triticirepentis were used. Plants were sprayed to drip stage, incubated overnight in a dark dew chamber at approximately 20 to $22^{\circ} \mathrm{C}$, and returned to diurnal conditions. Disease development was subsequently monitored and secondary or tertiary leaves for wheat and bromegrass, respectively, were harvested at 5 to 8 dpi to document the infection phenotype. Inoculations were repeated at least two to four times with similar results.

\section{RNA extraction and DNase treatment.}

RNA was extracted per a modification of the manufacturer's instructions for the RNeasy plant mini kit (Qiagen, Valencia, CA, U.S.A.) from fungal tissue grown in modified Fries medium (Tomas and Bockus 1987) at $25^{\circ} \mathrm{C}$ under constant illumination for 10 days (i.e., in culture) or from fungal infected leaf tissue of the wheat cv. Katepwa or line 6B662 harvested at 2 dpi (i.e., in planta). Either type of tissue $(200 \mathrm{mg})$ was ground in liquid nitrogen followed by the immediate addition of 900 $\mu \mathrm{l}$ of RNeasy lysis buffer RLT and incubation at $56^{\circ} \mathrm{C}$ for 2 min with constant mixing. After vortexing for $30 \mathrm{~s}, 750 \mu \mathrm{l}$ was transferred to a QIAshredder minispin column for homogenization, and $450 \mu \mathrm{l}$ of the flow-through was processed as described by the manufacturer's instructions, including the optional on-column DNase digestion with the RNase-Free DNase set (Qiagen). Further DNA removal was achieved by treatment with TURBO DNase as described for the TURBO DNA-free kit (Ambion, Austin, TX, U.S.A.). RNA samples were diluted to $9 \mu \mathrm{g}$ per $40 \mu \mathrm{l}$ prior to treatment, and two applications of TURBO DNase were applied followed by a 30-min incubation at $37^{\circ} \mathrm{C}$ each time. Prior to subsequent analyses, all RNA samples were screened by PCR with ToxB-specific primers for contamination with genomic DNA.

\section{Semiquantitative RT-PCR.}

For each sample, first-strand cDNA was synthesized from $1.5 \mu \mathrm{g}$ of total RNA as described in the manufacturer's instructions for SuperScript II reverse transcriptase (Invitrogen, Carlsbad, CA, U.S.A.). Two cDNA reactions of each type were subsequently combined (for a total of $3 \mu \mathrm{g}$ of RNA per sam- ple), treated with RNase, and concentrated on a MinElute spin column (Qiagen), which served to remove degraded RNA, as well as the poly-dT primer (as was done by Martinez and colleagues [2004]). PCR was then used to analyze the following: i) $10 \%$ of the combined cDNA reaction and ii) $300 \mathrm{ng}$ of the original RNA sample, which corresponds to the total amount of RNA found in $10 \%$ of the combined cDNA reaction and serves as a control to rule out contamination with genomic DNA. RNA-only controls were free of contaminating genomic DNA for all sample sets (data not shown).

Primer TB7F (which is identical to ToxB but has one nucleotide difference with all of the $P b \operatorname{Tox} B$ loci) (Martinez et al. 2001) and TB59R (which is identical to all of the $P b$ ToxB loci but has one nucleotide difference with ToxB) (Martinez et al. 2004) were used to detect a 193- and 196-bp fragment of ToxB and $P b$ ToxB, respectively. Before using this primer set in reactions with cDNA, it was shown to amplify similarly from equivalent amounts of $P$. tritici-repentis and $P$. bromi genomic DNA (data not shown). Primers gpdl and gpd2 (Berbee et al. 1999), which were designed to amplify an approximately 600bp fragment from genomic DNA (exon + intron sequence), were used to detect an approximately 450-bp fragment from cDNA (just exon sequence) of the gpd gene, our housekeeping gene of choice (Fang and Bidochka 2006; Grell et al. 2005). This primer set was also shown to amplify similarly from equivalent amounts of $P$. tritici-repentis and $P$. bromi genomic DNA (data not shown). Noninoculated controls confirm that our gpd primers are specific to fungi and do not recognize plant gpd sequences (Fig. 5C). Genomic DNA extraction procedures were previously described (Andrie et al. 2007).

PCR reactions $(50 \mu \mathrm{l})$ consisted of $1 \times$ Taq polymerase buffer (50 $\mathrm{mM} \mathrm{KCl}, 1.5 \mathrm{mM} \mathrm{MgCl}_{2}$, and $10 \mathrm{mM}$ Tris $\cdot \mathrm{HCl}, \mathrm{pH} 9.0$ ), $200 \mu \mathrm{M}$ each dNTP, $200 \mathrm{nM}$ each primer, and $2.5 \mathrm{U}$ of Taq polymerase (MBI Fermentas, Hanover, MD, U.S.A.). Amplification was carried out as follows: 1 cycle of $94^{\circ} \mathrm{C}$ for $3 \mathrm{~min}$; 35 cycles of $94^{\circ} \mathrm{C}$ for $45 \mathrm{~s}, 55^{\circ} \mathrm{C}$ for $35 \mathrm{~s}$, and $72^{\circ} \mathrm{C}$ for $55 \mathrm{~s}$; and 1 cycle of $72^{\circ} \mathrm{C}$ for $7 \mathrm{~min}$. To maximize detection of potentially rare $\mathrm{Pb}$ ToxB transcripts, the amplification products from two PCR reactions were combined, treated with RNase, and concentrated prior to visualization via standard agarose gel electrophoresis. Samples with ToxB were treated identically. The identity of all amplification products was confirmed via sequence analysis (Central Services Laboratory, Center for Genome Research and Biocomputing, Oregon State University, Corvallis, OR, U.S.A.). PCR reactions were repeated at least twice in culture for each isolate analyzed, as well as 6 times in $P$. tritici-repentis-inoculated wheat and 10 times in $P$. bromi-inoculated wheat.

\section{Heterologous expression in Pichia pastoris.}

Constructs for heterologous expression in Pichia pastoris were assembled in accordance with the instructions for the EasySelect Pichia expression kit (Invitrogen). The $\alpha$-factor signal sequence from Saccharomyces cerevisiae present in vector $\mathrm{pPICZ} \alpha \mathrm{B}$ was chosen for heterologous expression based on preliminary results that revealed superior expression from this signal sequence compared with the native signal sequence (data not shown). Platinum Taq DNA polymerase high fidelity (Invitrogen) was used per the manufacturer's instructions to amplify each mature protein sequence without its signal sequence. For use in subsequent cloning steps, the primers PbTB1F (5'-TAGCTCGAGAAAAGAAACTGCATCGCCAA TATC-3') and TB16R (Martinez et al 2001) introduced a 5' XhoI site and 3' NotI site, respectively, in each amplification product. Gel-purified (Qiagen) amplification products were subsequently digested with XhoI and NotI and cloned flush with the Kex2 cleavage site of expression vector pPICZ $\alpha \mathrm{B}$, 
followed by transformation into Escherichia coli XL1-Blue competent cells (Stratagene, La Jolla, CA, U.S.A.). Positive clones for each coding sequence were confirmed via sequence analysis. Constructs were subsequently linearized with SacI for transformation into Pichia pastoris X-33 competent cells as specified in the instructions for the Pichia EasyComp kit (Invitrogen).

For heterologous expression, positive Pichia pastoris clones were grown in buffered minimal methanol media as specified by the kit. Each culture filtrate was lyophilized, resuspended in water to approximately $1 / 10$ the original volume, and desalted on a PD-10 desalting column per the manufacturer's instructions (GE Healthcare, Piscataway, NJ, U.S.A.). Multiple unsuccessful attempts were made to remove the large Pichia proteins present in all samples (data not shown); therefore, we relied on culture filtrate from Pichia pastoris X-33 transformed with the $\mathrm{pPICZ} \alpha$ vector alone for a negative control.

\section{Detection and quantitation \\ of heterologously expressed proteins.}

Heterologously expressed protein samples were fractionated by $13 \%$ SDS-PAGE in conjunction with the buffer system of Fling and Gregerson (1986) and detected with the SilverSNAP stain kit II (Pierce Biotechnology, Inc., Rockford, IL, U.S.A.). Comparison of the protein products to the MultiMark MultiColored Standard (Invitrogen) confirmed that each was approximately $6.5 \mathrm{kDa}$ in size (Fig. 2B), except Ptr toxb, which had an additional, larger doublet (Fig. 3A). To estimate the amount of heterologously expressed protein of interest in each culture filtrate, ImageQuaNT 5.0 (Molecular Dynamics Inc., Sunnyvale, CA, U.S.A.) was used for densitometric analysis of a digital scan of the silver-stained SDS-PAGE gel as described by the manufacturer's instructions. The intensity of two bands for each protein was averaged and compared with a standard curve of pure homogenous native Ptr ToxB standards, including 75, 150, 225, and $350 \mathrm{ng}$ (Fig. 2B). To assist in the quantitation of heterologously expressed Ptr toxb, the two bands seen in Figure 3A were left unresolved in the gel seen in Figure 2B. For leaf infiltration bioassays, the concentration of each heterologous protein was diluted to $9.5,19$, and $38 \mathrm{ng} / \mu \mathrm{l}$, which were chosen based on known physiologically relevant concentrations of native Ptr ToxB (Strelkov et al. 1999) and of heterologously expressed Ptr ToxB (Martinez et al. 2001). To rule out an effect of Pichia pastoris proteins present in each culture filtrate, we infiltrated the vector-only control at full strength (i.e., it was undiluted as compared with the dilutions described above for the culture filtrates of the heterologous proteins).

\section{Western blot analysis of heterologously expressed proteins.}

Protein samples were fractionated as described above, followed by equilibration of the gel in transfer buffer $(25 \mathrm{mM}$ Tris Base, $193 \mathrm{mM}$ glycine, and 20\% methanol) and dry transfer of proteins to GE nitrocellulose pure transfer membrane (GE Osmonics, Minnetonka, MN, U.S.A.). Resultant blots were blocked overnight at $4^{\circ} \mathrm{C}$ in $1 \times$ TBST $(150 \mathrm{mM} \mathrm{NaCl}$, $0.05 \%$ Tween 20, and $10 \mathrm{mM}$ Tris-HCL, $\mathrm{pH} 8.0$ ) and $3 \%$ nonfat dried milk. Blots were then washed in $1 \times$ TBST, followed by incubation for $1 \mathrm{~h}$ in anti-Ptr ToxB antisera diluted 1:2,000 in $1 \times$ TBST and $1 \%$ bovine serum albumin fraction V. Blots were again washed, followed by incubation for $30 \mathrm{~min}$ in antirabbit horseradish peroxidase-conjugated secondary antibody (Sigma-Aldrich, St. Louis) diluted 1:80,000 in 1× TBST. Following a final wash, blots were developed via chemiluminescence in accordance with manufacturer's instructions for the SuperSignal West Dura Extended Duration Substrate (Pierce Biotechnology, Inc.). Western analyses were repeated with at least two sets of independently expressed proteins.
Bioassay of heterologously expressed proteins.

A modified Hagborg device (Hagborg 1970) was used to infiltrate heterologously expressed proteins into secondary and tertiary leaves of wheat and bromegrass, respectively. Three leaves were infiltrated per treatment, after which plants were returned to the growth chamber. Leaves were harvested at either day 5 or day 7 postinfiltration for wheat and bromegrass, respectively, and the extent of chlorosis was documented via digital scanning. Infiltrations were repeated with two to four sets of independently expressed proteins.

\section{ACKNOWLEDGMENTS}

We thank S. Ali for isolates of P. bromi; P. Martinez for the Ptr ToxB antibody; U.S. National Plant Germplasm System, United States Department of Agriculture-Agricultural Research Service for Bromus inermis seed; V. Manning for technical assistance, discussion, and critical review; I. Pandelova for discussion and critical review; and T. Wolpert for critical review. This project was supported by a grant to L. Ciuffetti from the National Research Initiative Biology of Plant-Microbe Associations of the United States Department of Agriculture Cooperative State Research, Education and Extension Service (grant number 2003-35319-13476).

\section{LITERATURE CITED}

Aboukhaddour, R., Cloutier, S., Ballance, G. M., and Lamari, L. 2009. Genome characterization of Pyrenophora tritici-repentis isolates reveals high plasticity and independent chromosomal location of ToxA and ToxB. Mol Plant Pathol. 10:201-212.

Ali, S., and Francl, L. 2003. Population race structure of Pyrenophora tritici-repentis prevalent on wheat and noncereal grasses in the Great Plains. Plant Dis. 87:418-422.

Ali, S., Francl, L. J., and De Wolf, E. D. 1999. First report of Pyrenophora tritici-repentis race 5 from North America. Plant Dis. 83:591.

Amaike, S., Ozga, J. A., Basu, U., and Strelkov, S. E. 2008. Quantification of ToxB gene expression and formation of appressoria by isolates of Pyrenophora tritici-repentis differing in pathogenicity. Plant Pathol. 57:623-633.

Andrie, R. M., Pandelova, I., and Ciuffetti, L. M. 2007. A combination of phenotypic and genotypic characterization strengthens race designation of Pyrenophora tritici-repentis. Phytopathology 97:694-701.

Andrie, R. M., Schoch, C. L., Hedges, R., Spatafora, J. W., and Ciuffetti, L. M. 2008. ToxB, a host-selective toxin gene from Pyrenophora triticirepentis, is present in the genome of sister-species $P$. bromi and other members of the Ascomycota. Fungal Genet. Biol. 45:363-377.

Ballance, G. M., Lamar, L., Kowatsch, R., and Bernier, C. C. 1996. Cloning, expression, and occurrence of the gene encoding the Ptr necrosis toxin from Pyrenophora tritici-repentis. Mol. Plant Pathol. Online only: http://www.bspp.org.uk/mppol/1996/1209ballance.

Barker, N. P., Clark, L. G., Davis, J. I., Duvall, M. R., Guala, G. F., Hsiao, C., Kellogg, E. A., Linder, H. P., Mason-Garner, R. J., Mathews, S. Y. Simmons, M. P., Soreng, R. J., and Spangler, R. E. 2001. Phylogeny and subfamilial classification of the grasses (Poaceae). Ann. Mo. Bot. Gard. 88:373-457.

Berbee, M. L., Pirseyedi, M., and Hubbard, S. 1999. Cochliobolus phylogenetics and the origin of known, highly virulent pathogens, inferred from ITS and glyceraldehyde-3-phosphate dehydrogenase gene sequences. Mycologia 91:964-977.

Berg, C. C., Zeiders, K. E., and Sherwood, R. T. 1989. Registration of PLBDR1 smooth bromegrass germplasm. Crop Sci. 29:1578.

Campbell, M. A., Medd, R. W., and Brown, J. F. 2003. Phytotoxicity of metabolites produced by Pyrenophora semeniperda in liquid culture. Aust. J. Exp. Agric. 43:1237-1244.

Cao, T., Kim, Y. M., Kav, N. N. V., and Strelkov, S. E. 2009. A proteomic evaluation of Pyrenophora tritici-repentis, causal agent of tan spot of wheat, reveals major differences between avirulent and virulent isolates. Proteomics 9:1177-1196.

Chamberlain, D. W., and Allison, J. L. 1945. The brown leaf spot of Bromus inermis caused by Pyrenophora bromi. Phytopathology 35:241-248.

Ciuffetti, L. M., and Tuori, R. P. 1999. Advances in the characterization of the Pyrenophora tritici-repentis-wheat interaction. Phytopathology 89:444-449.

Ciuffetti, L. M., Tuori, R. P., and Gaventa, J. M. 1997. A single gene encodes a selective toxin causal to the development of tan spot of wheat. Plant Cell 9:135-144.

Ciuffetti, L. M., Manning, V. A., Pandelova, I., Betts, M. F., and Martinez, 
J. P. 2010. Host-selective toxins, Ptr ToxA and Ptr ToxB, as necrotrophic effectors in the Pyrenophora tritici-repentis-wheat interaction. New Phytol. 187:911-919.

De Wolf, E. D., Effertz, R. J., Ali, S., and Francl, L. J. 1998. Vistas of tan spot research. Can. J. Plant Pathol. 20:349-444.

Dushnicky, L. G., Ballance, G. M., Sumner, M. J., and MacGregor, A. W. 1998. The role of lignification as a resistance mechanism in wheat to a toxin-producing isolate of Pyrenophora tritici-repentis. Can. J. Plant Pathol. 20:35-47.

Eriksson, O. E. 2005. Outline of the Ascomycota-2005. Myconet 11:1113.

Fang, W., and Bidochka, M. J. 2006. Expression of genes involved in germination, conidiogenesis and pathogenesis in Metarhizium anisopliae using quantitative real-time RT-PCR. Mycol. Res. 110:1165-1171.

Fling, S. P., and Gregerson, D. S. 1986. Peptide and protein molecular weight determination by electrophoresis using a high-molarity Tris buffer system without urea. Anal. Biochem. 155:83-88.

Friesen, T. L., Faris, J. D., Solomon, P. S., and Oliver, R. P. 2008. Hostspecific toxins: effectors of necrotrophic pathogenicity. Cell. Microbiol. 10:1421-1428.

Grell, M. N., Holm, K. B., and Giese, H. 2005. Two novel Blumeria graminis f. sp. hordei genes are induced in planta and up-regulated in mlo virulent isolates. Physiol. Mol. Plant Pathol. 66:79-89.

Haegi, A., and Porta-Puglia, A. 1995. Purification and partial characterization of a toxic compound produced by Pyrenophora graminea. Physiol. Mol. Plant Pathol. 46:429-444.

Hagborg, W. A. F. 1970. A devise for injecting solutions and suspensions into thin leaves of plants. Can. J. Bot. 48:1135-1136.

Henikoff, S., and Henikoff, J. G. 1992. Amino acid substitution matrices from protein blocks. Proc. Natl. Acad. Sci. U.S.A. 89:10915-10919.

Hsiao, C., Chatterton, N. J., Asay, K. H., and Jensen, K. B. 1994. Phylogenetic relationships of 10 grass species: an assessment of phylogenetic utility of the internal transcribed spacer region in nuclear ribosomal DNA in monocots. Genome 37:112-120.

Kim, Y. M., and Strelkov, S. E. 2007. Heterologous expression and activity of Ptr ToxB from virulent and avirulent isolates of Pyrenophora triticirepentis. Can. J. Plant Pathol. 29:232-242.

Lamari, L., and Bernier, C. C. 1989. Evaluation of wheat lines and cultivars to tan spot [Pyrenophora tritici-repentis] based on lesion type. Can. J. Plant Pathol. 11:49-56.

Lamari, L., Sayoud, R., Boulif, M., and Bernier, C. C. 1995. Identification of a new race in Pyrenophora tritici-repentis: implications for the current pathotype classification system. Can. J. Plant Pathol. 17:312-318.

Lamari, L., Strelkov, S. E., Yahyaoui, A., Orabi, J., and Smith, R. B. 2003. The identification of two new races of Pyrenophora tritici-repentis from the host center of diversity confirms a one-to-one relationship in tan spot of wheat. Phytopathology 93:391-396.

Larez, C. R., Hosford, J., R. M., and Freeman, T. P. 1986. Infection of wheat and oats by Pyrenophora tritici-repentis and initial characterization of resistance. Phytopathology 76:931-938.

Lichter, A., Gaventa, J. M., and Ciuffetti, L. M. 2002. Chromosome-based molecular characterization of pathogenic and non-pathogenic wheat isolates of Pyrenophora tritici-repentis. Fungal Genet. Biol. 37:180189

Martinez, J. P., Ottum, S. A., Ali, S., Francl, L. J., and Ciuffetti, L. M. 2001. Characterization of the ToxB gene from Pyrenophora tritici-repentis. Mol. Plant-Microbe Interact. 14:675-677.

Martinez, J. P., Oesch, N. W., and Ciuffetti, L. M. 2004. Characterization of the multiple-copy host-selective toxin gene, ToxB, in pathogenic and nonpathogenic isolates of Pyrenophora tritici-repentis. Mol. Plant-Microbe Interact. 17:467-474.

Oliver, R. P., and Solomon, P. S. 2008. Recent fungal diseases of crop plants: is lateral gene transfer a common theme? Mol. Plant-Microbe Interact. 21:287-293.

Orolaza, N. P., Lamari, L., and Ballance, G. M. 1995. Evidence of a hostspecific chlorosis toxin from Pyrenophora tritici-repentis, the causal agent of tan spot of wheat. Phytopathology 85:1282-1287.

Pfeffer, S. R., and Rothman, J. E. 1987. Biosynthetic protein transport and sorting by the endoplasmic reticulum and golgi. Annu. Rev. Biochem. 56:829-852.

Powell, A. J., Conant, G. C., Brown, D. E., Carbone, I., and Dean, R. A.
2008. Altered patterns of gene duplication and differential gene gain and loss in fungal pathogens. BMC Genomics 9:147.

Sampson, M. G., and Watson, A. K. 1985. Host specificity of five leaf-spotting pathogens of Agropyreon repens. Can. J. Plant Pathol. 7:161-164.

Sarpeleh, A., Wallwork, H., Catcheside, D. E. A., Tate, M. E., and Able, A. J. 2007. Proteinaceous metabolites from Pyrenophora teres contribute to symptom development of barley net blotch. Phytopathology 97:907-915.

Schoch, C. L., Shoemaker, R. A., Seifert, K. A., Hambleton, S., Spatafora, J. W., and Crous, P. W. 2006. A multigene phylogeny of the Dothideomycetes using four nuclear loci. Mycologia 98:1041-102.

Sherwood, R. T. 1996. Anatomical and physiological mechanisms of resistance to brown leaf spot in smooth bromegrass. Crop Sci. 36:239-242.

Soanes, D. M., Richards, T. A., and Talbot, N. J. 2007. Insights from sequencing fungal and oomycete genomes: what can we learn about plant disease and the evolution of pathogenicity? Plant Cell 19:3318-3326.

Strange, R. N. 2007. Phytotoxins produced by microbial plant pathogens. Nat. Prod. Rep. 24:127-144.

Strelkov, S. E., and Lamari, L. 2003. Host-parasite interactions in tan spot [Pyrenophora tritici-repentis] of wheat. Can. J. Plant. Pathol. 25:339349.

Strelkov, S. E., Lamari, L., and Ballance, G. M. 1999. Characterization of a host-specific protein toxin (Ptr ToxB) from Pyrenophora tritici-repentis. Mol. Plant-Microbe Interact. 12:728-732.

Strelkov, S. E., Lamari, L., Sayoud, R., and Smith, R. B. 2002. Comparative virulence of chlorosis-inducing races of Pyrenophora tritici-repentis. Can. J. Plant Pathol. 24:29-35.

Strelkov, S. E., Kowatsch, R. F., Ballance, G. M., and Lamari, L. 2006 Characterization of the ToxB gene from North African and Canadian isolates of Pyrenophora tritici-repentis. Physiol. Mol. Plant Pathol. 67:164-170.

Thompson, D. A., and Regev, A. 2009. Fungal regulatory evolution: cis and trans in the balance. FEBS (Fed. Eur. Biochem. Soc.) Lett. 583:3959-3965.

Thon, M. R., Pan, H., Diener, S., Papalas, J., Taro, A., Mitchell, T. K., and Dean, R. A. 2006. The role of transposable element clusters in genome evolution and loss of synteny in the rice blast fungus Magnaporthe oryzae. Genome Biol. 7:R16.

Tomas, A., and Bockus, W. W. 1987. Cultivar-specific toxicity of culture filtrates of Pyrenophora tritici-repentis. Phytopathology 77:1337-1340.

Tomas, A., Feng, G. H., Reeck, G. R., Bockus, W. W., and Leach, J. E 1990. Purification of a cultivar-specific toxin from Pyrenophora triticirepentis, causal agent of tan spot of wheat. Mol. Plant-Microbe Interact. $3: 221-224$

Tuori, R. P., Wolpert, T. J., and Ciuffetti, L. M. 1995. Purification and immunological characterization of toxic components from cultures of Pyrenophora tritici-repentis. Mol. Plant-Microbe Interact. 8:41-48.

Turgeon, B. G., and Baker, S. E. 2007. Genetic and genomic dissection of the Cochliobolus heterostrophus Toxl locus controlling biosynthesis of the polyketide virulence factor T-toxin. Adv. Genet. 57:219-261

Walton, J. D. 1996. Host-selective toxins: agents of compatibility. Plant Cell 8:1723-1733.

Weiergang, I., Jørgensen, H. J. L., Møller, I. M., Friis, P., and SmedegaardPetersen, V. 2002. Correlation between sensitivity of barley to Pyrenophora teres toxins and susceptibility to the fungus. Physiol. Mol. Plant Pathol. 60:121-129.

Wohlbach, D. J., Thompson, D. A., Gasch, A. P., and Regev, A. 2009. From elements to modules: regulatory evolution in Ascomycota fungi. Curr. Opin. Genet. Dev. 19:571-578.

Wolpert, T. J., Dunkle, L. D., and Ciuffetti, L. M. 2002. Host-selective toxins and avirulence determinants: what's in a name? Annu. Rev. Phytopathol. 40:251-285

Xu, J.-R., Peng, Y.-L., Dickman, M. B., and Sharon, A. 2006. The dawn of fungal genomics. Annu. Rev. Phytopathol. 44:337-366.

Zeiders, K. E., and Sherwood, R. T. 1986. Reactions of smooth bromegrass accessions to brown leaf spot caused by Pyrenophora bromi. Plant Dis. 70:324-326.

Zhang, G., and Berbee, M. L. 2001. Pyrenophora phylogenetics inferred from ITS and glyceraldehyde-3-phosphate dehydrogenase gene sequences. Mycologia 93:1048-1063.

Zolan, M.E. 1995. Chromosome-length polymorphism in fungi. Microbiol. Rev. 59:686-698. 